\title{
ROBOTOK ÉS A SAJTOLÓ HEGESZTÉSEK FEJLESZTÉSEI
}

\section{DEVELOPMENTS OF INDUSTRIAL ROBOTS AND PRESSURE WELDING PROCESSES}

\author{
Bitay Enikő $^{1}$, Bagyinszki Gyula ${ }^{2}$ \\ ${ }^{I}$ Sapientia - Erdélyi Magyar Tudományegyetem, Müszaki és Humántudományok \\ Kar, Románia, 540485 Marosvásárhely (Koronka), Segesvári út 1.C., \\ ebitay@ms.sapientia.ro \\ ${ }^{2}$ Óbudai Egyetem, Bánki Donát Gépész és Biztonságtechnikai Mérnöki Kar, Magya- \\ rország, 1081 Budapest, Népszínház u. 8, bagyinszki.gyula@bgk.uni-obuda.hu
}

\begin{abstract}
More than a third of the global robot market in the automotive sector orders make up the robot's sales growth too primarily in the automotive industry due to investment growth. The car factories and suppliers are usually the welding, the assembling and painting robots dominate and a significant application of the pressure welding processes. This article picks improvements of this profession field.

Keywords: welding, robot, special equipment

\section{Összefoglalás}

A globális robotpiac több mint harmadát az autóipar megrendelései teszik ki, a roboteladások bővülése is elsősorban a jármüipari beruházások növekedésének köszönhető. Az autógyárakban és beszállítói körükben rendszerint a hegesztő, az összeszerelő és a festő robotok a dominálnak, továbbá igen jelentős a sajtoló hegesztési eljárások alkalmazása. Jelen cikk ezen szakterület fejlesztéseiből válogat.
\end{abstract}

Kulcsszavak: hegesztés, robot, célberendezés

\section{Robottechnika}

Az elterjedt csuklókaros humanoid vagy antropomorf 6-tengelyes (6 szabadságfokú) robotok gazdag - terherbírás, illetve méret - választékán alapuló fejlesztési trendek:

- Alkalmazás-specifikus robotkarok gyártása, melyek az adott alkalmazásra - pl. ellenállás ponthegesztés, szerelés szabva kompromisszumok nélküli felhasználást tesznek lehetővé [1].

- Olyan, „még inkább humanoid” robotkarok (karpárok) gyártása [2], melyek akár 15 vezérelt tengellyel rendelkezhetnek (1. ábra), teljesen robottesten belülre rejtve az alkalmazástechnikai (elektromos, pneumatikus) kábeleket. Ez a fajta „emberkarakter” egyedülállóan új perspektívát nyit(hat) az alkalmazások, illetve munkahumanizálás elött.

- Az egyedi tervezésü rendszerek mellett kedvezőbb árfekvésű típusrendszerek állnak rendelkezésre igen rövid szállítási határidővel, többek között a védőgázos ívhegesztés és forrasztóhegesztés, az ellenállás ponthegesztés, a lemezalakító gépek vagy sajtoló hegesztő (cél)gépek kiszolgálása területén. 


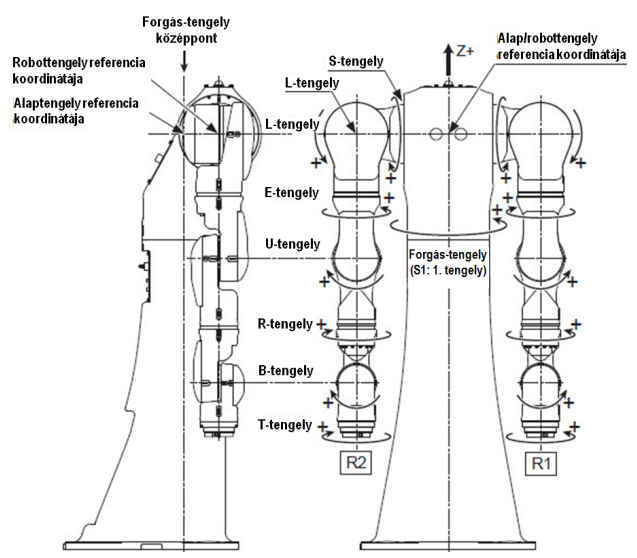

1. ábra. 15 tengelyes robot

A kompakt technológiai cellák által támasztott alkalmazástechnikai igényeket a kicsi, könnyü és dinamikus robotok elégítik ki jól. A mérsékelt tömegnek és ezáltal kisebb erökaroknak köszönhetően a robot nagyobb sebességre, illetve jobb visszaállási pontosságra képes. A ,jigless application" pl. ikerrobotos, készülék nélküli ívhegesztő robotrendszert jelent, melynél a munkadarabot nem hagyományos hegesztő készülék pozícionálja a robot előtt, hanem azt a manipulátor (kiszolgáló) robot - általában viszonylag egyszerü felfogással - tartja, illetve állítja be a hegesztő (technológiai) robot elé. Ezzel jelentős - tervezést, gyártást, munkadarab-pozícionálóra telepítést mellőző - készülék-költség megtakarítás érhető el.

$\mathrm{Az}$ újabb robotvezérlések akár 72 tengely egyidejü vezérlését is lehetővé teszik, pl. 8 robot és további külső tengelyek (forgatók, pozícionálók) szinkronvezérlésű mozgatásával. Ezek, illetve a kis helyigényü robotkarok lehetőséget adnak ,nagysürüségü" robotrendszerek kialakítására. A vezérlések korszerü üzemmódja jelentős energia-megtakarítást, környezetkonformitást eredményez, csökkentve a gyártás költségeit is. A vezérlésekhez tartozó kézi programozó pult ergonomikus kialakításánál fontos szempont - a funkciók és kezelőszervek felhasználó-barát elrendezése mellett - a minél kisebb kézzel tartandó önsúly is [1].

\section{Sajtoló hegesztések}

A 21-es számjelű ellenállásponthegesztés gépei helyhez kötöttek (kézi, illetve gépi kiszolgálásúak) vagy mozgathatók, manipulálhatók (pl. robotkarra erősíthetők) lehetnek. Ez utóbbi révén könnyen megvalósítható az automatizálás (pl. karosszéria elemek gyártósori hegesztése során). A középfrekvenciás ( $\mathrm{MF}=$ Medium Frequency) ellenállás ponthegesztés az egyenirányított háromfázisú $50 \mathrm{~Hz}$-es váltakozó áramot (AC) inverter (váltóirányító és frekvencia-átalakító) alkalmazásával 1000 Hz-re konvertálja, majd a hegesztőfejbe integrált transzformátor és szekunder köri egyenirányító segítségével a hegesztéshez szükséges szintű egyenáramot (DC) juttat az elektródákon keresztül a hegesztés helyére (2. ábra).

A hagyományos $50 \mathrm{~Hz}$-es váltakozó áramú hegesztéssel [3] összehasonlítva több technikai és beavatkozási előnyt nyújt [4]:

- a háromfázisú átalakításnak köszönhetően lehetőség van fázis-balanszra, miáltal kevésbé érzékeny a hegesztés az elektromos hálózat ingadozásaira;

- a nagyobb müködési frekvenciának, ezáltal könnyebb és kompaktabb transzformátornak köszönhetöen jobb hatásfok, szélesebb áramerösség-tartomány állítható be, továbbá a robotosított hegesztésnél kisebb a karrendszer terhelése is;

- mivel nincs áram-fluktuáció, 15 százalékkal rövidebbek a hegesztési időtartamok;

- tisztább a hegesztés, mivel elmarad a hagyományos hegesztésre jellemző szikrázás;

- a jó szabályozhatóságnak köszönhetően problémás hegeszthetőségű anyagokhoz is alkalmazható, mint pl. nagy szilárd- 
ságú acélokhoz, alumíniumhoz, egzotikus ötvözetekhez (különleges öntöttvasak, titán, szuperötvözetek, hőálló fémek), laminált acél/polimer
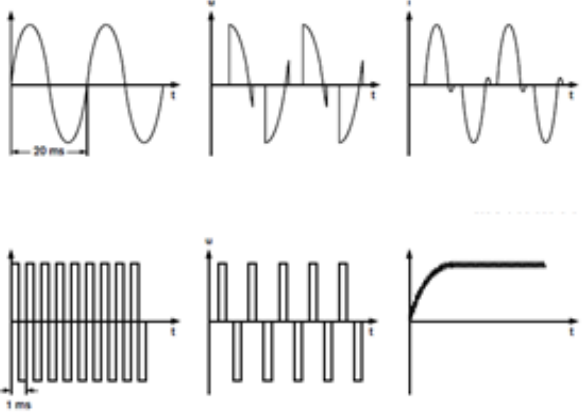

2. ábra. Hagyományos és középfrekvenciás ellenállás ponthegesztés

További fejlesztés a folyamat közbeni ellenőrzés és az ehhez kapcsolt szabályozás alkalmazása.

$\mathrm{Az}$ ellenállásponthegesztésnél a lencse méretének ultrahangos ellenőrzésére épülő szerkezetbe integrált - folyamatszabályozással nemcsak egyenletesebb minőség érhető el, de a tapasztalatok szerint az elektróda kopása is csökken.

A 41-es számjelü ultrahangos (pont-, vonal- és kör-) hegesztésekkel lehetőség van azonos vagy eltérő anyagminőségü lemezek és huzalok összekötésére. Az ultrahangos fémhegesztés előnyei [5]:

- Rendkívül rövid hegesztési idő;

- Nem kell semmilyen hegesztőanyag;

- Csekély elektromos átmeneti ellenállás;

- Hélium-tömör hegesztési varrat;

- A hegesztési felület viszonylag kis pontra, vonalra vagy körformájú felületre korlátozódik;

- A hegesztési paraméterek számítógépes ellenőrzése és statisztikus kiértékelése egyszerüen megoldható;

- Tiszta és biztonságos munkafolyamat (nincs szikra, láng és füst), ezért környezetbarát;

- Nagyon csekély energiafelhasználás;

- Automatizált gyártósorba integrálható.

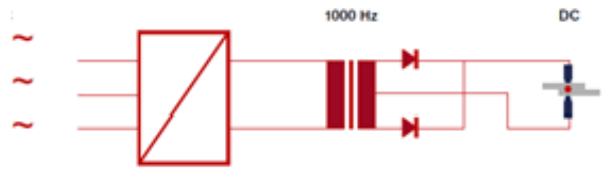

kompozitokhoz, bevonatolt acélokhoz, többrétegü termékekhez.

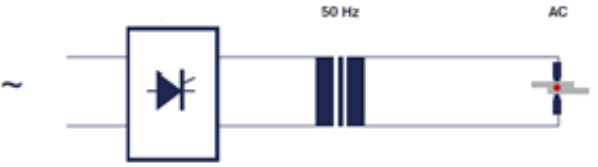

A 43-as számjelü kavaró dörzshegesztésnél egy forgó, kopásálló anyagból készített alakos (csapszerü) szerszám és a tompán illesztett, szilárd alátétre lefogott lemezek között képződő súrlódási hőt hasznosítják. A szerszám először lassan, nagy erővel a két lemez kötési övezetébe merül, majd beindul a hosszirányú előtolás. A szerszám az összekötendő anyagokat (könnyü- és színesfémeket) meglágyítja, megkavarja (,átgyúrja”), majd a csap menti válla révén a felületet tömöríti és elsimítja. Ilyen módon az alapanyagok intenzív melegalakítása révén, azok megolvadása nélkül jön létre hegesztett kötés. Jellemzően célgépes kivitelben alkalmazzák.

A kavaró dörzs-ponthegesztést speciálisan autóipari alkalmazásokhoz fejlesztették ki, beleértve alumínium darabok egymáshoz, illetve Al és acél alkatrészek vegyes kötését. A folyamat lépései hasonlóak a normál kavaró dörzshegesztéséhez, de itt nincs varratvonal-menti mozgatás, azaz pontszerü kötés alakul ki (3. ábra) [6]. 


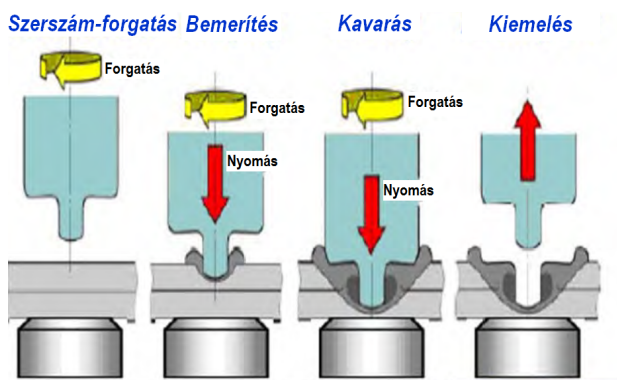

3. ábra. Kavaró dörzs-ponthegesztés

A 442-es számjelü mágnesimpulzusos hegesztés elektromágnesesen generált erőket alkalmaz (4. ábra), miáltal szilárd állapotú sajtolóhegesztés valósul meg. Alakító tekercseken keresztül feltöltött kondenzátortelepet sütnek ki, miáltal létrejövő erős áramimpulzus igen nagy mágneses indukciót generál a hegesztés helyén. A hegesztendő darabban indukált áram és a mágneses mező kölcsönhatása következtében radiális irányú dinamikus (robbanáshoz hasonló) mechanikai erőhatás jön létre. Ez a hegesztendő felületeket összeütközteti és a felületmenti anyagrészek képlékeny alakváltozása következtében alakul ki a sajtolva hegesztett kapcsolat.
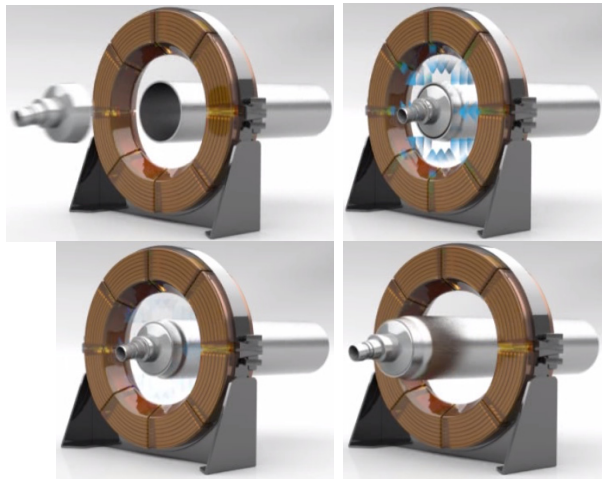

4. ábra. Mágnesimpulzusos hegesztés fázisai

Az eljárás előnyei [7]:

- Lehetővé teszi más eljárással nem vagy csak problémásan hegeszthető darabok kötését.
- Különböző fémek összehegesztése is lehetséges.

- Rendkívül gyors, a tipikus impulzusidőtartam $10 \ldots 100 \mu$ s, így termelékenységi korlátot a munkadarab adagolás sebessége jelent.

- Megbízható és jól illeszkedik a nagy volumenü termelésbe.

- Alacsonyak a költségei, magas minőséggel és termelékenységgel társulva.

- Nincs szükség hozaganyagra, védőgázra.

- Nem szükséges a kötések elözetes vagy utólagos kezelése.

- Kiváló minőségű, esztétikus és tiszta felület érhető el.

- Zöld folyamat, azaz nincs környezetet terhelö hevítés, szikrázás, füst, sugárzás.

- Gyakorlatilag nincs hőhatásövezet.

- Nem romlik a kötés szilárdsága, sőt nagyobb mint az alapanyagé.

- Nem jön létre korrózió a hegesztési zónában.

\section{Szakirodalmi hivatkozások}

[1] Bagyinszki Gyula: Automatizálás és intelligens gyártás, Hegesztéstechnika XXIV. évfolyam 2013. 4. szám, 22-30. o.

[2] Specifications of MOTOMAN Dual Arm Robots, http://www.dualarmrobot.com/ specifications.html (2016. 01. 10.)

[3] Bagyinszki Gyula - Bitay Enikő: Hegesztéstechnika I. - Eljárások és gépesités, Erdélyi Múzeum-Egyesület, Kolozsvár, 2010, 288 oldal

[4] Rewroth Bosch Group: Automotive Industry Technology Update - Welding, Cambridgeshire, 2005, p. 6

[5] Ultrahangos fémhegesztés, THONAUER information Nr.3, 2 oldal

[6] Technical Editors: Stuart Keele \& Menachem Kirachi: Advanced HighStrenght Steels Application Guidelines Version 5.0, WorldAutoSteel, May 2014, p. 276

[7] Magnetic Pulse Welding, http://www.bmax.com/technology/magneticpulse-welding (2016. 01. 10.) 